JURNAL ILMIAH AGRINECA

ISSN : 2721-074X (Online) - 2301-6698 (Print)

Available on : http://ejournal.utp.ac.id/index.php/AFP/index

This is Under CC BY SA Licence

\title{
PENGARUH DOSIS PUPUK KANDANG KAMBING TERHADAP HASIL BEBERAPA MACAM VARIETAS TANAMAN KEDELAI (Glycine max L)
}

\section{Effect of Dosage Goats Fertilizer to The Yield of Soybean Varieties ( Glycine max L)}

\author{
Nur Muhamad Bagus Setiawan*, Setie Harieni, Wiyono \\ Program Agroteknologi, Fakultas Petanian, Universitas Tunas Pembangunan \\ Surakarta \\ Jl. Balekambang Lor, No.1 Surakarta \\ *Corresponden author: snurmuhamadbagus@gmail.com
}

\begin{abstract}
The 2015 soybean needs were 963.10 thousand tons of cable mining. Increased by 8.10 thousand tons (0.85 percent) compared to 2014. The increase in production occurred outside Java as much as 30.41 thousand tons, while in Java there was a decline in production by 22.31 thousand tons. The increase in soybean production occurred because of an increase in productivity of 0.18 quintal / hectare (1.16 percent) even though the harvested area had decreased by 1.80 thousand hectares $(0.29$ percent). This study aims to determine the effect of goat manure doses on the growth and yield of soybean plants, to determine the effect of soybean varieties on goat manure doses and to determine the interaction between goat manure doses and soybean plant varieties. The study was conducted in Teguhan Village, Karangmalang District, Sragen Regency, with an altitude of 86 asl with grumusol soil types. This study uses a Randomized Complities Block Design consisting of 2 factors. The first factor was goat manure dosage and the second factor was soybean crop varieties and repeated 3 times. The research factors referred to as follows: 1) Factor I, Dose of goat manure $(K)$ is $K_{0}: 0 \mathrm{~kg} /$ ha (control), $K_{1}: 10$ tons / ha, $K_{2}: 20$ tons / ha, K3: 30 tons / ha , 2) Factor II, Types of Soybean Varieties $(V)$, namely $V_{1}$ : Grobogan, $V_{2}$ : Burangrang, $V_{3}$ : Baluran. Each treatment was repeated 3 times. The results of this study are 1) The treatment of goat manure doses on all parameters with the use of a dose of 20 tons / ha shows the average yield different from other parameters, the treatment of varieties shows that the baluran variety is the best yield compared to the other two varieties all research parameters, 2) the interaction between manure doses and soybean varieties on all parameters of the study showed no significant difference. 3) for soybean yields at the highest seed weight per plot in the treatment of the Baluran variety was $299.5 \mathrm{~g}(2.11$ tons / ha) and the lowest was in the conventional treatment of Grobogan which was $206 \mathrm{~g}$ (1.39 tons /ha).
\end{abstract}

Keywords: Dose of Goat Manure, Types of Soybean Varieties

\begin{abstract}
ABSTRAK
Kebutuhan kedelai tahun 2015 sebanyak 963,10 ribu ton biji kering. Meningkat sebanyak 8,10 ribu ton $(0,85$ persen) dibandingkan tahun 2014. Peningkatan produksi tersebut terjadi di luar Pulau Jawa sebanyak 30,41 ribu ton, sementara di Pulau Jawa terjadi penurunan produksi sebanyak 22,31 ribu ton. Peningkatan produksi kedelai terjadi karena kenaikan produktivitas sebesar 0,18 kuintal/hektar (1,16 persen) meskipun luas panen mengalami penurunan seluas 1,80 ribu hektar $(0,29$ persen). Penelitian ini bertujuan untuk mengetahui pengaruh dosis pupuk kandang kambing terhadap pertumbuhan dan hasil tanaman kedelai, untuk mengetahui pengaruh varietas tanaman kedelai terhadap dosis pupuk kandang kambing dan untuk mengetahui interaksi antara dosis pupuk kandang kambing dengan varietas tanaman kedelai. Penelitian dilaksanakan di Desa Teguhan Kecamatan
\end{abstract}


JURNAL ILMIAH AGRINECA

ISSN : 2721-074X (Online) - 2301-6698 (Print)

Available on : http://ejournal.utp.ac.id/index.php/AFP/index

This is Under CC BY SA Licence

\begin{tabular}{cccccccc} 
& \multicolumn{9}{c}{$(\mathrm{g})$} & \multicolumn{5}{c}{} & $(\mathrm{g})$ & \\
\cline { 2 - 7 } & $46,22 \mathrm{a}$ & $30,07 \mathrm{a}$ & $1.295,67$ & $305,78 \mathrm{a}$ & 11,44 & 258,11 & 17,67 \\
$\mathrm{~K} 0$ & $52,37 \mathrm{~b}$ & $34,37 \mathrm{c}$ & $1.260,56$ & $367,78 \mathrm{bc}$ & 14,15 & 268,11 & 17,33 \\
$\mathrm{~K} 1$ & $51,31 \mathrm{ab}$ & $32,67 \mathrm{ab}$ & $1.370,67$ & $361,22 \mathrm{ab}$ & 13,78 & 258,22 & 17,33 \\
$\mathrm{~K} 2$ & $49,07 \mathrm{ab}$ & $32,83 \mathrm{bc}$ & $1.046,22$ & $391,33 \mathrm{c}$ & 14,41 & 274,89 & 17,00 \\
$\mathrm{~K} 3$ &
\end{tabular}

Keterangan : angka-angka yang diikuti huruf yang sama pada kolom yang sama menunjukkan tidak berbeda nyata berdasarkan uji DMRT taraf $5 \%$.

Hasil uji lanjut pada tabel di atas menunjukkan pemberian dosis pupuk kandang 10 ton/ha $\left(\mathrm{K}_{1}\right)$ ternyata meningkatkan jumlah polong per tanaman, namun tidak meningkatkan jumlah polong per petak, sedangkan peningkatan dosis pupuk kandang melebihi dosis tersebut $\left(K_{2}\right.$ dan $\left.K_{3}\right)$ ternyata diperoleh jumlah polong yang tidak meningkat melebihi $\mathrm{K}_{1}$.

Pemberian dosis pupuk kandang 10 ton/ha $\left(\mathrm{K}_{1}\right)$ ternyata juga meningkatkan berat polong per tanaman maupun berat polong per petak, namun peningkatan melebihi dosis tersebut ternyata diperoleh berat polong per tanaman maupun per petak yang tidak meningkat melebihi $\mathrm{K}_{1}$.

Hal ini menunjukkan bahwa peningkatan ketersediaan unsur hara mampu memberikan pengaruh pada jumlah polong per tanaman dan berat polong per tanaman. Berat polong per petak pada perlakuan 30 ton/ha $\left(\mathrm{K}_{3}\right)$ lebih tinggi dan berbeda nyata dengan Kontrol $\left(\mathrm{K}_{0}\right)$. Jumlah polong tertinggi pada perlakuan $\mathrm{K}_{1}(10 \mathrm{ton} / \mathrm{ha})$ yaitu $52,37 \mathrm{~g}$ berbeda nyata dengan $\mathrm{K}_{0}, \mathrm{~K}_{2}$ dan $\mathrm{K}_{3}$ dengan urutan rata-rata jumlah polong $46,22 \mathrm{~g}, 51,31 \mathrm{~g}$ dan 49,07 g. Terlihat pada perlakuan dosis pupuk kandang kambing $\mathrm{K}_{1}$ (10 ton/ha ) memberikan hasil yang nyata dibandingkan dengan pemberian dosis pupuk kandang kambing yang semakin tinggi ( Lampiran 10 ). Hal ini dikarenakan pada lahan penelitan sebelumnya masih terkandung hara dari sisa tanaman padi.

Jumlah polong dipengaruhi oleh pupuk kandang kambing dimana dalam perlakuan 10 ton/ha mampu menghasilkan jumlah polong yang lebih banyak dibandingakan dengan tanpa perlakuan $\mathrm{K}_{0}$ ( Kontrol ). Menurut Muharam (2017), pemberian pupuk kandang sebagai sumber pupuk organik mampu meningkatkan kandungan hara, menurunan $\mathrm{pH}$ tanah, dan mempunyai daya mengikat air dalam tanah untuk menyediakan nutrisi bagi pertumbuhan tanaman, sehingga tanaman dapat tumbuh dengan baik. Dengan minimnya unsur hara yang terkandung didalam tanah, maka akan menurunkannya hasil produksi pada suatu tanaman. Penambahan pupuk kandang kambing dapat meningkatkan kemampuan tanah dalam mengikat air, kapasitas tanah untuk menahan air berhubungan dengan struktur dan tekstur tanah.

Perlakuan dosis pupuk kandang kambing berpengaruh sangat nyata terhadap berat polong per tanaman. Berat polong tanaman tertinggi pada $\mathrm{K}_{1}(10$ ton/ha) yaitu $34,37 \mathrm{~g}$ berbeda nyata dengan $\mathrm{K}_{0}, \mathrm{~K}_{2}$ dan $\mathrm{K}_{3}$ dengan urutan nilai rata-rata $30,07 \mathrm{~g}, 32,67 \mathrm{~g}$ dan $32,83 \mathrm{~g}$. Berdasarkan hasil sidik ragam ( lampiran 11 ) berpengaruh sangat nyata pada pemberian pupuk kandang kambing terhadap berat polong per tanaman. Lingga dan Marsono (2007) menjelaskan bahwa peranan nitrogen bagi tanaman adalah untuk merangsang pertumbuhan secara keseluruhan, khususnya cabang, batang dan daun. Nitrogen berfungsi sebagai pembentuk klorofil, protein dan lemak. Nitrogen juga sebagai penyusun enzim yang terdapat dalam sel, sehingga mempengaruhi pertumbuhan karbohidrat yang sangat berperan dalam pertumbuhan tanaman.

Perlakuan dosis pupuk kandang kambing berpengaruh nyata terhadap berat polong per petak. Berat polong per petak 
JURNAL ILMIAH AGRINECA

ISSN : 2721-074X (Online) - 2301-6698 (Print)

Available on : http://ejournal.utp.ac.id/index.php/AFP/index

This is Under CC BY SA Licence

dan periode reproduktif. Periode vegetatif adalah periode tumbuh mulai munculnya tanaman di permukaan tanah sampai terbentuknya bunga pertama. Lama periode vegetatif tergantung dari genotip dan lingkungan, terutama panjang hari dan suhu (Hidajat, 1985).

Periode reproduktif menyusul periode vegetatif. Periode pengisian biji merupakan periode yang paling kritis dalam masa pertumbuhan kedelai. adanya gangguan pada periode ini dapat berakibat pada hasil tanaman menurun. Jumlah maksimum polong tiap tanaman dan ukuran biji ditentukan secara genetik, namun jumlah nyata polong dan ukuran nyata biji yang terbentuk dipengaruhi oleh lingkungan sewaktu proses pengisian biji (Hidadjat, 1985).

Tabel 3 Hasil Analisis Tanah Sebelum Penelitian

\begin{tabular}{ccccc}
\hline \multicolumn{4}{c}{ Analisis Tanah Sebelum Penelitian } \\
\hline C organik (\%) & $\begin{array}{c}\text { Bahan Organik } \\
(\%)\end{array}$ & N Total $(\%)$ & P Total (\%) & $\begin{array}{c}\text { K Tertukar (me } \\
\%)\end{array}$ \\
\hline 1,46 & 2,52 & 0,24 & 0,16 & 0,21 \\
\hline
\end{tabular}

Sumber : Hasil analisis laboratorium kimia dan kesuburan tanah Fakultas

Pertanian Universitas Sebelas Maret Surakarta. 2018

bahwa C.Organik tanah sebelum

dilakukan penelitian yaitu $1,46 \%$.

Diketahui bahwa kandungan bahan organik tanah sangat rendah yaitu $2,52 \%$. Rendahnya kandungan bahan organik dalam tanah berhubungan dengan kandungan $\mathrm{N}$ total tanah. Pada lokasi penelitian ini kandunga $\mathrm{N}$ total di dalam tanah sebelum penelitian rendah yaitu $0,24 \%$. Dari analisis kandungan $\mathrm{P}$ dalam tanah sebelum penelitian yaitu $0,16 \%$. K tersedia di dalam tanah sebelum penelitian tergolong rendah yaitu $0,21 \%$.

Tabel 4 Hasil Analisis Tanah Setelah Penelitian

\begin{tabular}{cccccc}
\hline \multirow{2}{*}{ Perlakuan } & \multicolumn{5}{c}{ Analisis Tanah Setelah Penelitian } \\
\cline { 2 - 5 } & $\begin{array}{c}\text { C Organik } \\
(\%)\end{array}$ & $\begin{array}{c}\text { Bahan Organik } \\
(\%)\end{array}$ & N Total $(\%)$ & $\begin{array}{c}\text { P Total } \\
(\%)\end{array}$ & $\begin{array}{c}\text { K Tertukar } \\
(\text { me } \%)\end{array}$ \\
\hline K0 & 1,24 & 2,13 & 0,29 & 0,08 & 0,31 \\
K1 & 1,28 & 2,20 & 0,32 & 0,11 & 0,35 \\
K2 & 1,31 & 2,26 & 0,38 & 0,15 & 0,41 \\
K3 & 1,43 & 2,46 & 0,41 & 0,15 & 0,44 \\
\hline Rata-rata & 1,31 & 2,26 & 0,35 & 0,30 & 0,37 \\
\hline
\end{tabular}

Sumber : Hasil analisis laboratorium kimia dan kesuburan tanah Fakultas

Pertanian Universitas Sebelas Maret Surakarta. 2018

Dari hasil analisis tabel di atas pemberian dosis pupuk kandang kambing memberikan pengaruh $\mathrm{N}$ total tanah. $\mathrm{N}$ total mengalami perubahan tetapi tidak signifikan $(0,30-0,50)$. Hasil analisis menunjukkan bahwa $\mathrm{N}$ total terus mengalami kenaikan $0,2-0,4 \%$ dari $\mathrm{N}$ total tanah sebelum penlitian yaitu $0,24 \%$. Kandungan $\mathrm{N}$ tertinggi terdapat pada perlakuan $\mathrm{K}_{3}$ yaitu $0,41 \%$ tetapi tidak berbeda nyata dengan perlakuan $\mathrm{K}_{2}$ yaitu $0,38 \%$. Sedangkan $\mathbf{N}$ total terendah pada perlakuan pupuk kandang kambing $\mathrm{K}_{0}$ yaitu $0,29 \%$.

Hasil analisis $\mathrm{K}$ tertukar pada tanah tertinggi pada perlakuan $\mathrm{K}_{3}$ yaitu 0,44 me\% berbeda dengan sebelum penelitian yaitu $0,21 \mathrm{me} \%$. Hal ini dapat diartikan $\mathrm{K}$ tertukar yang masih tertinggal didalam tanah sekitar $0,23 \mathrm{me} \%$. Seddangkan nilai 


\section{AGRINECA}

JURNAL ILMIAH AGRINECA

ISSN : 2721-074X (Online) - 2301-6698 (Print)

Available on : http://ejournal.utp.ac.id/index.php/AFP/index

This is Under CC BY SA Licence

terendah pada perlakuan $\mathrm{K}_{0}$ yaitu dengan

nilai $0,31 \mathrm{me} \%$. 

JURNAL ILMIAH AGRINECA

ISSN : 2721-074X (Online) - 2301-6698 (Print)

Available on : http://ejournal.utp.ac.id/index.php/AFP/index

This is Under CC BY SA Licence

Tabel 5 Hasil Analisis Pupuk Kandang Kambing

\begin{tabular}{|c|c|c|c|}
\hline \multicolumn{4}{|c|}{ Analisis Pupuk Kandang Kambing } \\
\hline N Total $(\%)$ & N Tersedia $(\%)$ & P Tersedia (ppm) & K Tersedia $(\%)$ \\
\hline 2,14 & 0,047 & 113,64 & 0,08 \\
\hline
\end{tabular}

Sumber : Hasil analisis laboratorium kimia dan kesuburan tanah Fakultas

Pertanian Universitas Sebelas Maret Surakarta. 2018

Berdasarkan hasil analisis pupuk kandang kambing (tabel 5), diketahui bahwa pupuk kandang kambing memiliki kandungan $\mathrm{N}$ total $2,14 \%, \mathrm{~N}$ Tersedia $0,047 \%$, P Tersedia $113,64 \%$ dan K Tersedia 0,08\%. Dengan adanya penambahan pupuk kandang kambing diharapkan dapat meningkatkan kesuburan tanah dan menyediakan unsur hara yang cukup bagi tanaman. Pupuk kandang kambing selain memiliki unsur hara yang penting tersebut juga dapat memperbaiki sifat fisik tanah.

\section{KESIMPULAN}

Perlakuan dosis pupuk kandang kambing menunjukkan pengaruh nyata pada, jumlah polong per tanaman, berat polong per tanaman dan berat polong per petak, tetapi tidak berbeda nyata pada perlakuan, berat biji per tanaman, berat biji per petak, berat polong per petak dan berat 100 biji.

Perlakuan macam varietas menunjukkan pengaruh nyata terhadap perlakuan jumlah polong per tanaman, berat polong per tanaman, berat polong per petak dan berat biji per petak, tetapi tidak berbeda nyata pada perlakuan berat biji per tanaman, , berat polong per petak dan berat 100 biji.

Hasil kedelai pada berat biji per petak tertinggi pada perlakuan varietas Baluran yaitu 299,5 g ( 2,11 ton/ha ) dan terendah pada perlakuan verietas Grobogan yaitu $206 \mathrm{~g}$ ( 1,39 ton/ha ).

\section{DAFTAR PUSTAKA}

Adisarwanto. 2006. Budidaya Dengan Pemupukan yang Efektif dan Pengoptimalan Peran Bintil Akar Kedelai. Penebar Swadaya. Jakarta. 108 Hlm.
Andrianto, T. T. Dan N. Indarto 2004. Budidaya dan Analisis Usaha Tani: Kedelai, Kacang Hijau, Kacang Panjang. Cetakan Pertama. Penerbit Absolut. Yogyakarta. Hal 9 - 92.

Badan Pusat Statistika. 2018. Produksi Kedelai Nasional. Jakarta.

Hidajat. 1985. Tanaman Kedelai. Puslitbangtan. Bogor.

Hariyadi, B. W., Huda, N., Ali, M., \& Wandik, E. (2019). The Effect of Tambsil Organic Fertilizer on The Growth And Results of Onion (Allium Ascalonicum L.) In Lowland. Agricultural Science, 2(2), 127-138.

Lingga dan Marsono. 2007. Petunjuk Penggunaan Pupuk. Penebar Swadaya. Jakarta. $150 \mathrm{Hal}$

Ludgate, Patrick J. and Patricia. 1989. Kumpulan Peragaan dalam Rangka Penelitian Ternak Kambing dan Domba di Pedesaan. Balai penelitian Ternak. Pusat Penelitian dan pengembangan Peternakan. Bogor: Badan Litbang Peternakan.

Muharam. 2017. Efektivitas Penggunaan Pupuk Kandang dan Pupuk Organik Cair dalam Meningkatkan Pertumbuhan dan Hasil Tanaman Kedelai (Glycine Max. L) Varietas Anjasmoro di Tanah Salin. Jurnal Agrotek Indonesia 2 (1) : $44-53$

Pitojo. 2003. Benih Kedelai. Kanisius. Yogyakarta

Simanungkalit. 2006. Pupuk Organik dan Pupuk Hayati. Balai Besar Penelitian dan Pengembangan Sumber Daya Lahan Pertanian. Bogor

Subandi, A. Harsono dan H. Kuntyastuti 2015. Areal Pertanaman Dan Sistem Produksi Kedelai Di Indonesia.. Pusat Penelitian dan Pengembangan Tanaman Pangan, Bogor. Hal 104-129

Sukmawati. 2013. Respon Tanaman Kedelai Terhadap Pemberiaan Pupuk Organik Inokulasi FMA Dan Varietas Kedelai Di Tanah Pasiran. Universitas Nahdlatul Wathan 


\section{AGRINECA}

\section{JURNAL ILMIAH AGRINECA}

ISSN : 2721-074X (Online) - 2301-6698 (Print)

Available on : http://ejournal.utp.ac.id/index.php/AFP/index

This is Under CC BY SA Licence

Mataram, Riau. Jurnal volume 7, No. 4, Juli 2013. ISSN No. 1978- 3787.

Winarti, S. Sundari, Y. dan Asie, Y. 2016. Pertumbuhan Dan Hasil Tanaman Kedelai (Glycine Max (L) Merr) Yang Diberi Pupuk
Kotoran Kambing Dan Rhizobium Sp Pada Tanah Gambut. Fakultas Pertanian Universitas Palangka Raya. Kalteng. Jurnal AGRI PEAT, Volume. 17 No. 2, September 2016 : 79-89. ISSN

:1411 $-6782$ 